J. Clin. Chem. Clin. Biochem.

Vol. 15, 1977, pp. 615-617

\title{
Non-Destructive Neutron Activation Analysis of Copper in Liver Samples and other Biological Materials
}

\author{
By D. Behne, P. Brätter, W. Gatschke, D. Gawlik and U. Rösick
}

Hahn-Meitner-Institut für Kernforschung Berlin

(Received March 21/June 7, 1977)

Summary: Neutron activation analysis via the short-lived radionuclide ${ }^{66} \mathrm{Cu}$ was applied in the determination of the level of copper in tissues. With this procedure the samples are analysed non-destructively and can therefore be used for further histological tests. The applicability of the method in the analysis of biopsy samples is discussed.

\section{Zerstörungsfreie Neutronen-Aktivierungsanalyse von Kupfer in Leberproben und anderem biologischen Material}

Zusammenfassung: Für die Bestimmung des Kupfergehaltes in Geweben wurde die Neutronen-Aktivierungsanalyse über das kurzlebige Radionuklid ${ }^{66} \mathrm{Cu}$ angewendet. Bei diesem Verfahren werden die Proben zerstörungsfrei untersucht und können deshalb danach für histologische Untersuchungen verwendet werden. Die Anwendbarkeit der Methode bei der Analyse von Biopsieproben wird diskutiert.

\section{Introduction}

Because of the relationships between pathological states and changes in the liver copper level, which can be used in diagnosis, the analysis of this element in liver biopsy specimens is of interest. In the analytical methods which are usually applied in the determination of copper in these samples, treatment of the tissue cannot be avoided. When using neutron activation analysis via the radionuclide ${ }^{64} \mathrm{Cu}(1,2,3)$, it is necessary to separate ${ }^{64} \mathrm{Cu}$ from other radionuclides such as ${ }^{24} \mathrm{Na}$, which likewise emit $\beta^{+}$-rays. In the case of biopsies, however, where the samples are relatively small and repeated sampling is difficult or impossible, it would be of advantage if the same material could be used for other tests too. Therefore it was the object of this study to find out whether neutron activation analysis via the short-lived radionuclide ${ }^{66} \mathrm{Cu}$ can be applied in this way in the determination of the element.

\section{Experimental}

The samples were irradiated without any further treatment at a thermal neutron flux density of $1.5 \cdot 10^{13} \mathrm{~cm}^{-2} \mathrm{~s}^{-1}$ in a pneu: matic tube system which was situated in a beam tube of the research reactor $\mathrm{BER}$ II in Berlin (4). Highly pure polyethylene vials with a copper content below the detection limit were used as sample containers. After a decay time of $1 \mathrm{~s}$ the gamma spectrum of the sample was measured four times for $120 \mathrm{~s}$ each, using a coaxial Ge(Li) detector. For the determination of the element the $1039 \mathrm{keV}-\gamma$ line of ${ }^{66} \mathrm{Cu}$ was evaluated.
For the analysis by flameless atomic absorption spectrometry the samples were digested with nitric acid at $160^{\circ} \mathrm{C}$ in a closed pressure vessel made of teflon. After atomization of the element in a graphite furnace at a temperature of $2500^{\circ} \mathrm{C}$ the absorption signals were measured by means of a double beam atomic absorption spectrophotometer, Perkin-Elmer Model 503.

\section{Results}

For the development and testing of the analytical procedure the National Bureau of Standards' reference material "Bovine Liver" was used, for which a certified copper content of $193 \pm 10 \mathrm{mg} / \mathrm{kg}$ (mean $\pm 95 \%$ confidence limits) had been published (5). In order to optimize the irradiation time, $100 \mathrm{mg}$-samples of this substance were activated for different periods varying between $5 \mathrm{~s}$ and 110 s. The specific initial counting rate for the $1039 \mathrm{keV}-\gamma$ peak of ${ }^{66} \mathrm{Cu}$, measured in these experiments, is shown in figure 1 together with its standard deviation.

Information about the sensitivity of the procedure and about the detection limit was obtained by irradiating different amounts of the standard. The results are shown in figure 2.

In order to find out whether systematic errors occur with this method, the copper content of some liver samples was determined by neutron activation analysis as well as by flameless atomic absorption spectrometry. The data for these analyses are listed in table 1. 


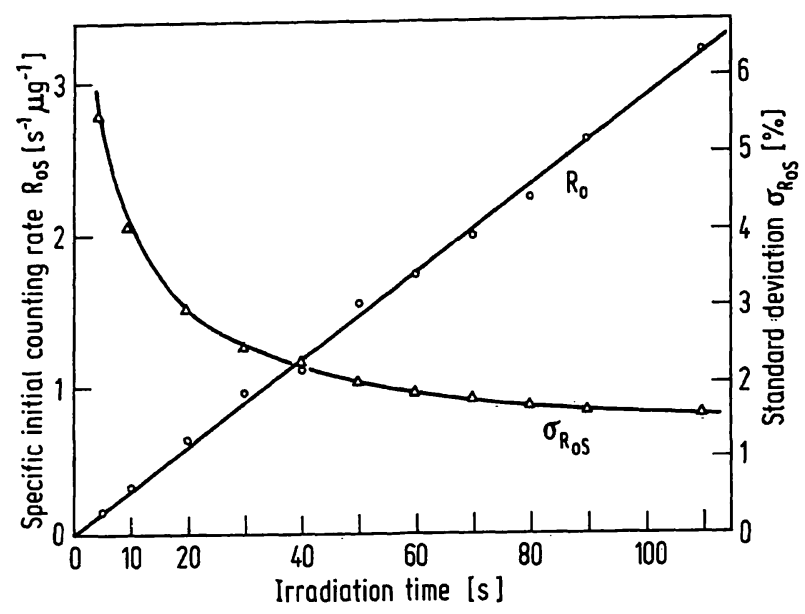

Fig. 1. Specific initial counting rate (per $\mu \mathrm{g} \mathrm{Cu}$ ) and its standard deviation for the ${ }^{66} \mathrm{Cu}$-gamma peak at $1039 \mathrm{keV}$, measured non-destructively in $100 \mathrm{mg}$-samples of the NBS-reference material "Bovine Liver" after different irradiation periods.

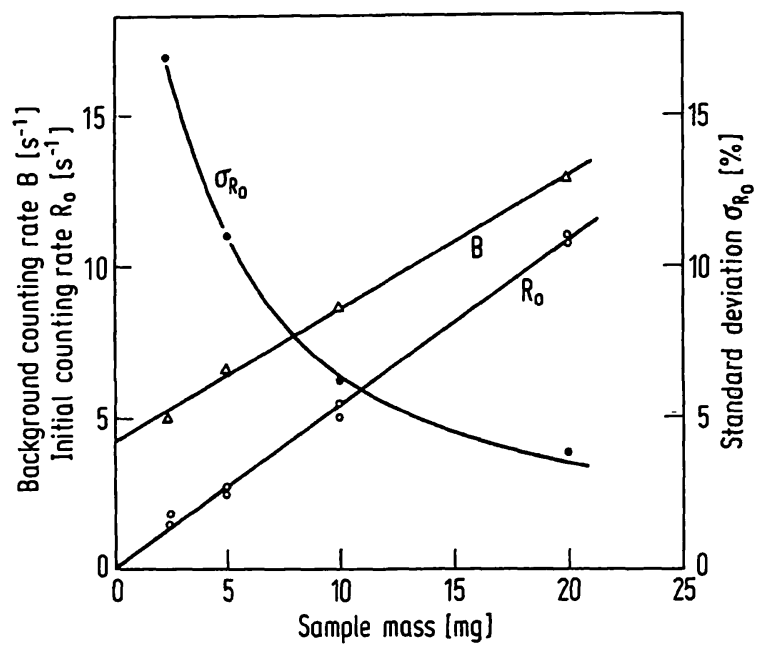

Fig. 2. Initial counting rate, its standard deviation and the background counting rate for the ${ }^{66} \mathrm{Cu}$-gamma peak at $1039 \mathrm{keV}$, measured in different amounts of the NBSreference material "Bovine Liver" after irradiation for $60 \mathrm{~s}$.

Tab. 1. Copper content in liver samples determined by neutron activation analysis (NAA) and atomic absorption spectrometry (AAS).

\begin{tabular}{|c|c|c|c|c|}
\hline & \multicolumn{2}{|l|}{ NAA } & \multicolumn{2}{|l|}{ AAS } \\
\hline & $\begin{array}{l}\text { No. } \\
\text { of } \\
\text { sam- } \\
\text { ples }\end{array}$ & $\begin{array}{l}\text { Content } \\
\mathrm{mg} / \mathrm{kg}^{2} \text { ) }\end{array}$ & $\begin{array}{l}\text { No. } \\
\text { of } \\
\text { sam- } \\
\text { ples }\end{array}$ & $\begin{array}{l}\text { Content } \\
\mathrm{mg} / \mathrm{kg}^{2} \text { ) }\end{array}$ \\
\hline $\begin{array}{l}\text { Rat liver } \\
\text { (dried) }\end{array}$ & 3 & $\left.22.5 \pm 3.8^{1}\right)$ & 3 & $18.6 \pm 1.9$ \\
\hline $\begin{array}{l}\text { Bovine liver } \\
\text { (wet) }\end{array}$ & 2 & $40.1 \pm 3.0$ & 2 & $44.0 \pm 3.7$ \\
\hline $\begin{array}{l}\text { Bovine liver } \\
\text { (dried) }\end{array}$ & 6 & $90.3 \pm 6.2$ & 2 & $101.8 \pm 11.1$ \\
\hline $\begin{array}{l}\text { Standard material } \\
\text { "Bovine Liver" }\end{array}$ & 4 & $185.3 \pm 10.0$ & 3 & $184.6 \pm 15.2$ \\
\hline
\end{tabular}

1) Mean \pm standard deviation

2) Calculated for the mentioned state of the sample.

\section{Discússion}

In this study the findings showed that it is possible to determine tissue copper levels non-destructively by short-time irradiation with thermal neutrons and gammaspectrometry of the short-lived radionuclide ${ }^{66} \mathrm{Cu}$.

For optimum conditions the irradiation time and the decay period after the activation had to be chosen so as to obtain a high level of ${ }^{66} \mathrm{Cu}$-radioactivity at low levels of interfering radionuclides. After a decay time of $1 \mathrm{~s}$ the main interference was caused by the gamma rays of ${ }^{24} \mathrm{Na}$ and ${ }^{38} \mathrm{Cl}$. From the data in figures 1 and 2 it was calculated that, as far as counting statistics are concerned, a minimum standard deviation ( $1 \%$ in the case of the reference material investigated) is obtained when the samples are irradiated for $650 \mathrm{~s}$. However, in order to reduce radiation damage as far as possible, a shorter irradiation period of $60 \mathrm{~s}$ was chosen. As shown in figure 1, the statistical error was then only increased to $2 \%$.

From the results for the copper analyses listed in table 1, it can be seen that the values obtained by neutron activation analysis agreed quite well with the atomic absorption data. The copper content determined in the reference material "Bovine Liver" was in accordance with the certified value from the National Bureau of Standards. These findings show that the analytical procedure is free of systematic errors.

From the calibration curve in figure 2 a sensitivity of $2.7 \mathrm{~s}^{-1} \mu \mathrm{g}^{-1}$ was calculated for the analysis of the element. For a sample mass of $300 \mathrm{mg}$ wet tissue the lower limit of detection at the $97.5 \%$ confidence level was found to be $1.5 \mu \mathrm{g} \mathrm{Cu}$, corresponding to a content of $5 \mathrm{mg} / \mathrm{kg}$. The limit of quantitative determination at which the standard deviation is $10 \%$, was reached at a copper content of $12.5 \mathrm{mg} / \mathrm{kg}$. As the sodium and chlorine levels, which are responsible for the main interference in the analysis, do not vary greatly, these limits are also valid for other tissues.

In the case of liver biopsies samples of about $5 \mathrm{mg}$ are available. For this sample mass a lower limit of detection of $0.35 \mu \mathrm{g} \mathrm{Cu}$ was calculated, corresponding to a content of $70 \mathrm{mg} / \mathrm{kg}$ wet weight. Here the limit of quantitative determination $(\sigma \leqslant 10 \%)$ was found to be $1 \mu \mathrm{g} \mathrm{Cu}$, corresponding to $200 \mathrm{mg} / \mathrm{kg}$ wet weight. These findings show that the method can be used for the copper analysis in the diagnosis of diseases such as Wilson's disease, for which abnormally high liver copper contents are characteristic (6).

The main advantage of this method is the fact that the sample is not destroyed during the analysis and can be used for further tests. As sample treatment is not necessary, the procedure involves relatively little work and can be easily automated. Ten minutes are required for one analysis including the data evaluation. 


\section{References}

1. Smallwood, R. A., Williams, H. A., Rosenoer, V. M. \& Sherlock, S. (1968), Lancet II, 1310-1313.

2. Schmid-Rüter, E., Feist, D., Wesch, H., Roßner, J. A. \& Schärer, K. (1973), Dtsch. Med. Wochenschr. 98, 16981703.

3. Leonhardt, W., Niese, S., Jaroß, W., Hanefeld, M., Schentke, K.-U. \& Meißner, D. (1975), Isotopenpraxis 11, 130-133.
4. Brätter, P., Gatschke, W., Gawlik, D., Möller, J. \& Wenckel, W. (1976), Report HMI-B 188.

5. LaFleur, P. D. (1974), J. Radioanal. Chem. 19, 227-232.

6. Cartwright, G. E. (1950), in "Symposium on Copper Metabolism" (McElroy, W. D. and Glass, B., eds.), p. 274, Johns Hopkins Press, Baltimore, Maryland.

Dr. Dietrich Behne

Bereich Kernchemie und Reaktor

Hahn-Meitner-Institut

für Kernforschung Berlin GmbH

Glienicker Straße 100

1000 Berlin 39 


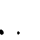

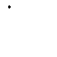

,

